\title{
Application-oriented Institutes Innovation Thinking and Practice of Talent Training Mode
}

\author{
Liucheng Zhang ${ }^{1, \text { a }}$ \\ ${ }^{1}$ The practice teaching management center,Harbin University of Commerce,Harbin,China \\ azhangliucheng@126.com
}

Keywords: Undergraduate Colleges.Innovation and entrepreneurship . Personnel training

\begin{abstract}
Colleges and universities , an important part of the national innovation system, implement innovation and entrepreneurship education in order to provide effective personnel and intellectual support , and the strategy that is "improve the capability of independent innovation, build an innovation oriented country," promoted employment by entrepreneurship "," speed up the transfor-mation of economic growth mode "put forward by the CPC Central Committee. This paper expounds the connotation of the application oriented universities and the innovation and entrepreneurship education, builds the training model of innovation and entrepreneurship, and applies it to the process of talent training in Harbin University of Commerce, and has achieved good results.
\end{abstract}

\section{Introduction}

From the perspective of reform and development of higher education, the sustainable development of higher education not only includes the scale development, but also the quality improvement, and the main task of the future development of higher education is to improve the quality of it. Our country has put the innovation and entrepreneurship education included in the essentials of country - long term educational reform and development ", and put the innovation and entrepreneurship education into the whole personnel training process, its core is to cultivate the students' abilities of innovation and entrepreneurship, the reform of talent training mode and content of education, make personnel training, scientific research and social service are tightly combined, realize the transformation from the emphasis on knowledge to pay more attention to the ability and the quality, improve the personnel training quality .With the important strategic significance and educational value, innovation and entrepreneurship education has been widely concerned and accepted by the University. It is a urgent problem to promote the development of innovation and entrepreneurship education effectively, to grasp the connotation of the concept, to analyze the bottleneck of restricting the development of the enterprise, and to build the feasible implementation plan .

\section{The Connotation Of The Application Oriented Undergraduate Institutions And Innovation And Entrepreneurship Education Platform Construction Ideas Type Area}

Higher education in our country can be divided into three categories: research, application and occupation. Application type undergraduate colleges is a higher education category or type refers to between research universities and vocational high designed, it's main task and objective is to cultivate applied talents, rather, research universities cultivate talents for research mainly, professional in Higher Vocational Colleges cultivate skill talents. Application type undergraduate education has distinct characteristics: on the training specifications, application type undergraduate education aims to train higher technology applied talents who adapt to the needs of production, construction, management and services ; on the training mode, application type undergraduate education aims to adapt the needs of society, Designs students' knowledge, ability, quality structure and training program regarding cultivate the abilities of application technology as the main line, construct system of curriculum and teaching content regarding the "application" as the purpose and characteristics, pay attention to training the students' ability to apply technology. 
Entrepreneurship education trains creative personality individual who should has creative, adventurous spirit, entrepreneurial ability, ability to work independently and has technical, social and management skills from the generalized. Innovative education regard cultivate people's innovative spirit and innovative ability as the basic value orientation. Entrepreneurship education is just put forward the concept overseas, while our country integrate it with enterprise education, and put forward the concept of innovation and entrepreneurship education, because innovation and entrepreneurship is inseparable, innovation is the foundation and core of entrepreneurship, entrepreneurship is the important embodiment forms of innovation.

\section{Construction Of Innovative And Entrepreneurial Talents Training Model In Applied Undergraduate Colleges}

Ersonnel training objectives.Application type undergraduate colleges' entrepreneurship education should be based on professional education, integrates innovation and entrepreneurship education into the basis of professional education, pays attention to the cultivation of students' innovative spirit and entrepreneurial ability and application ability, and improves the students' comprehensive quality and promote students' all-round development. The so-called in-novative spirit is to cultivate students the innovative consciousness to forge ahead and the courage to explore the spirit of innovation. The so-called entrepreneurial ability is to enable students to have set up a new enterprise and enterprise innovation ability, have different professional knowledge, skills and qualities in the future by cultivating students entrepreneurship awareness, knowledge business, experience entrepreneurial, foster the spirit of entrepreneurship. The so-called technical application ability is to cultivate students the knowledge, skills and practice ability, so that they are able to adapt to market competition, with speciality, quality, lifelong learning abilities.

Teaching system.Application oriented undergraduate colleges should build the innovation and entrepreneurship education model of "theory + practice + supplementary activities". The "theory" is mainly to set the relevant innovation and entrepreneurship courses for students, to impart the basic knowledge of innovation and entrepreneurship, because innovation and entrepreneurship activities are based on knowledge activities.

As for the curriculum design, innovation and entrepreneurship courses can be divided into required courses and elective courses. Set for all professional students, Compulsory courses mainly allow students to understand the basic concepts of innovation and entrepreneurship, theory and methods, have a basic understanding of innovative entrepreneurial activities. Relevant elective courses about innovation and entrepreneurship should be set based on it , focusing on the cultivation of students' innovative thinking and entrepreneurial awareness, to master the entrepreneurial knowledge, enhance entrepreneurial skills.

"Practice" is mainly to provide students with the opportunity to simulate the entrepreneurial and entrepreneurial opportunities. Business simulation is mainly to simulate the entire business process and enterprise operation and management in the real situation through the business software and enterprise management sand table, to strengthen students' understanding of the theory of entrepreneurship and enterprise management, to experience process of entrepreneurship and enterprise operation and management.

Business practice can be achieved through a variety of ways: schools and enterprises jointly build a base for innovation and entrepreneurship practice, students regularly enterprise all kinds of practice activities, understand the management of the enterprise, cultivate awareness of the entrepreneurial opportunity. Schools and enterprises can establish a joint training of student mechanisms for enterprise order type training and delivery of talent. Using this training mode, students can not only learn professional knowledge in the school, but also progress practical ability in the enterprise , get the guidance of enterprise technical personnel, and then students will soon be able to adapt to the work of enterprises.

Schools can establish innovation and entrepreneurship Technology Park, and select the project with development prospects and profitability stationed in innovation and entrepreneurship science and 
technology park. Innovative science and technology park provide policy legal advisory services, professional and technical advisory services, provide premises, offer phone, Internet access, necessary conditions for office, for entrepreneurial team, to encourage students to carry out innovation activities.

"Supplementary activities" is mainly stimulate students' enthusiasm for entrepreneurship, cultivate the entre-preneurial culture, explore the vision of students through the development of a number of related innovation and entrepreneurial activities . The school carry out business plan contest regularly, to improve student abilities that consult information, teamwork, analysis and solve the problem, through the entrepreneurial plan contest the popularity of entrepreneurial knowledge.

School provides team with professional guidance teachers, to further improve the entrepreneurial plan to participate in national, provincial and municipal entrepreneurship contest through the entrepreneurial plan contest selected outstanding works. Schools invited experts, academics and business executives for students to carry out innovation and entrepreneurship lectures at regular, to expand students' knowledge, broaden their horizons, deepen the understanding of innovation and entrepreneurial activity through these lectures.

Mode design." $3+1$ " teaching mode is before the school year in the school system study, all basic courses, specialized courses and innovative entrepreneurial curriculum learning could be finished, the fourth year comprehensive practice, innovation, entrepreneurship, employment practices could be carried out and graduation project or thesis could be completed based on it in the university four years of schooling arrangements.

The teaching mode of " $3+1$ " is an innovative attempt of talent training mode, which embodies the humanization of the talent training mode and the student oriented idea. " $3+1$ " personnel training mode makes the teaching content arranged more reasonable and compact. Traditional four-year talent training mode has many problems, such as loose arrangement of courses, too much spare time; indifferent to the practice teaching ; the seventh semester students are busy looking for work, the civil service exam, so that inadvertent class, school absenteeism rate higher. New talent training mode avoids these drawbacks, so that the whole teaching system preferable. " $3+1$ " talent training mode provides a platform for students to carry out practice, innovation, entrepreneurship and employment practice.

Students have limit time and opportunity to carry out the practice under the traditional 4 - year talent training mode. New talent training mode provides the students for up to 1 year to practice, in this year, students can carry out a variety of professional practice, innovation and entrepreneurship and employment practices, so as to improve the students hands-on ability, cultivate students' innovative thinking, experience business management process, but also can improve the rate of employment of students. "3+ 1 " talent training mode make the integration of school education and social education. The traditional school education take more teacher as the leadership to carry out the education, the initiative and enthusiasm of the students not to play, and the students cultivated like this have divorced with society, they need to go through a period of adaptation can be fully integrated into society. New talent training mode provide students with 1 year to contact and understanding the society, in this year , they will learn from society and life, accept social education, learn gradually to use knowledge they have learned to solve practical problems, enable students to integrate and adapt to society as soon as possible, reduced trouble from the school to the social ,through observation, thinking, behavior and feedback process.

Management and operation system.Application oriented undergraduate education innovation and entrepreneurship education should be led by the school practice teaching management department. The entrepreneurship and innovation institute and Entrepreneurship Education Center should be set .The relevant administrative departments carry out together. In related courses offering, the school entrepreneurship and innovation Institute or innovation and Entrepreneurship Education Center should offer innovative entrepreneurship required courses and related management, entrepreneurship, economic elective classes for school students and departments with their professional characteristics in offering some innovative courses. 
In the business plan competition, academic competition and the corresponding community activities, the school Entrepreneurship and innovation or innovation and Entrepreneurship Education Center is responsible for the organization and providing professional guidance teachers, while Communist Youth League and other departments are responsible for the activities of the publicity and student management work.

In the laboratory of innovation and entrepreneurship and the garden of science and technology management, the school is responsible for the overall construction of laboratory in science and Technology Park, the school entrepreneurship and innovation or innovation and Entrepreneurship Education Center is responsible for laboratory in science and technology park planning, daily management and operation. In the experimental personnel, facilities, fees and arrangement of teaching the implementation of unified management, faculties and students in the school can be in common use. Business innovation or innovation and entrepreneurship education center are equipped with professional teachers, to provide guidance, counseling and other services. Building such an innovation and entrepreneurship education management system is to ensure that the entire innovation and entrepreneurship education process has a professional teacher's participation and guidance, innovation and entrepreneurship education process can be completed in high quality.

\section{Innovation And Entrepreneurship Talent Training Practice In Harbin University Of Commerce}

Business innovation Institute ,set up by the school practice teaching management center, is responsible for all the students to carry out innovation and entrepreneurship courses and related management, entrepreneurship, economic class elective. And it is responsible for the organization to carry out the university student innovation competition and the discipline competition.

Course construction. Center open "entrepreneurship", "enterprise commercial simulation", the ERP enterprise simulation and operation "elective courses every year , and set the company was founded and operation" as the school of economics and management professional required courses, write teaching plan. After students completed 3 weeks the company create practice and operation in the center , they could obtain 3 credits in required and graduate.

Entrepreneurship competition and subject contest. Center set up a college student innovation and entrepreneurship alliance student organization. Under the guidance of the center , the organization carry out a variety of entrepreneurial competitions and academic competitions in the school. There is some competitions every year such as the challenge cup competition, national college management decision competition school trials, the university student's ERP sand table simulation contest campus tryouts, national investment and financial management for college students competition, National College of marketing competition and so on they have achieved outstanding results, won the provincial and ministerial level awards above 100 multinomial.

To carry out innovation and entrepreneurship training program for college students. Beginning in 2012, center carry out creativity and entrepreneurship training programs for school students and plan to approved 120 University Entrepreneurship and innovation projects, 50 national level projects, state-level projects given 10000 Yuan / funding, the project of the university give 1800-2200 Yuan / item funded every year. Independent innovation and entrepreneurial activities of College students is well promoted through the implementation of the project.

\section{Conclusions}

Regarding knowledge cross fusion entrepreneurship, innovation as a concept, the professional education as the foundation, we mix innovation and entrepreneurship education into the basis of professional education, and construct the application type undergraduate colleges' Entrepreneurship Talent Training mode, and we pays attention to the cultivation of students' innovative spirit and entrepreneurial ability and application ability. Let students take the initiative to form its own characteristics of the knowledge structure system through practice, and based on it, the knowledge 
obtained cross fusion through the real business practice, so as to enhance the students' entrepreneurial and innovative ability, effective innovation and entrepreneurial activity.

\section{Acknowledgements}

This work was financially supported by the Natural Social Science Foundation (15BJY017).

\section{References}

[1] Si Songmen, Zhuang Yale, Thinking about college students' innovative entrepreneurial training program [J], Journal of heilongjiang education (higher education research and evaluation), 2014, (7) , pp. 31-33.

[2] Zhang Li. Exploration of innovative thinking mode of application oriented personnel training,.2012 (19).62-63 of higher education in China

[3] Zhang Li. Deepen the reform of practical teaching to enhance students' Entrepreneurship and innovation ability. Laboratory research and exploration.2010 (3)

[4] Zhang Li.The design of the company to create and operate the practice program design. Laboratory science.2009 (5).171-172 